\title{
Псевдобинокулярные очки ночного видения с зеркально-линзовым и линзовым объективами
}

\author{
В.Г. Волков, П.Д. Гиндин, В.В. Карпов \\ Акционерное общество « Московский завод «САПФИР», Москва, 117545, \\ Днепропетровский проезд, 4A, стр. 3 \\ тел: + 7 (495) 312-02-03, факс: + 7 312-00-55, эл. почта: info@mzsapphir.ru
}

DOI 10.34077/RCSP2019-98

Известны псевдобинокулярные очки ночного видения (ОНВ) с линзовым объективом [1]. Предлагаемые псевдобинокулярные ОНВ (см. рисунок), содержат зеркально-линзовый объектив 1 с фокусным расстоянием $\mathrm{f}=60 \mathrm{Mм}$, углом поля зрения $2 \omega=15^{\circ}$. В центральной нерабочей части линзызеркала 2 установлена группа линз 5. Вместе с линзовым компенсатором 4 полевых аберраций объектива 1 эта группа 5 образует короткофокусный линзовый объектив. Для него $f=7,34$ мм, $2 \omega=$ $100^{\circ}$. Оба объектива сфокусированы на фотокатод диаметром 17,5 мм ЭОП 6. На его экран сфокусирована псевдобинокулярная окулярная система 7 . Ее увеличение $\Gamma=12,5^{\mathrm{x}}$, линейное поле зрения $21=17,5$ мм. При работе объектива 1 для ОНВ $\Gamma=3^{\mathrm{x}}$ при $2 \omega=15^{\circ}$. Для ОНВ при работе линзового объектива $\Gamma=0,3^{\mathrm{x}}$ при $2 \omega=100^{\circ}$. Линзовый объектив используется для поиска в широком угле поля зрения объекта наблюдения, а объектив 1 - для его распознавания. Фактически ОНВ с объективом 1 превращаются в наголовный бинокль. Дальность распознавания в него ростовой фигуры человека (РФЧ) в нормированных условиях составляет 300 м. Дальность обнаружения РФЧ в ОНВ с линзовым объективом с $2 \omega=100^{\circ}$ составляет 200 м. Схема ОНВ дополняется тепловизионным (ТВП) каналом. Его ИК объектив 8 оптически сопряжен с фотоприемным устройством (ФПУ) 9 , объединяющим матрицу микроболометров (МБМ) и электронный блок управления. Сигнал с его выхода передается в OLED дисплей 10. Его изображение с помощью линзового компонента 11 через полупрозрачное зеркало 12 оптически сопряжено с окулярной системой 7 и вводится в ее левый канал. ТВП канал работает в области спектра 8 - 12 мкм, имеет дальность распознавания РФЧ 300 м, $2 \omega=8 \times 12^{\circ}, \Gamma=1^{\mathrm{x}}$. На выходе полупрозрачного зеркала 12 установлен ТВ канал для дистанционной передачи изображения. Его объектив 13 сфокусирован на матрицу ПЗС ТВ камеры 14, и изображение с экрана ЭОП 6 и с OLED дисплея 10 вводится в TB канал.

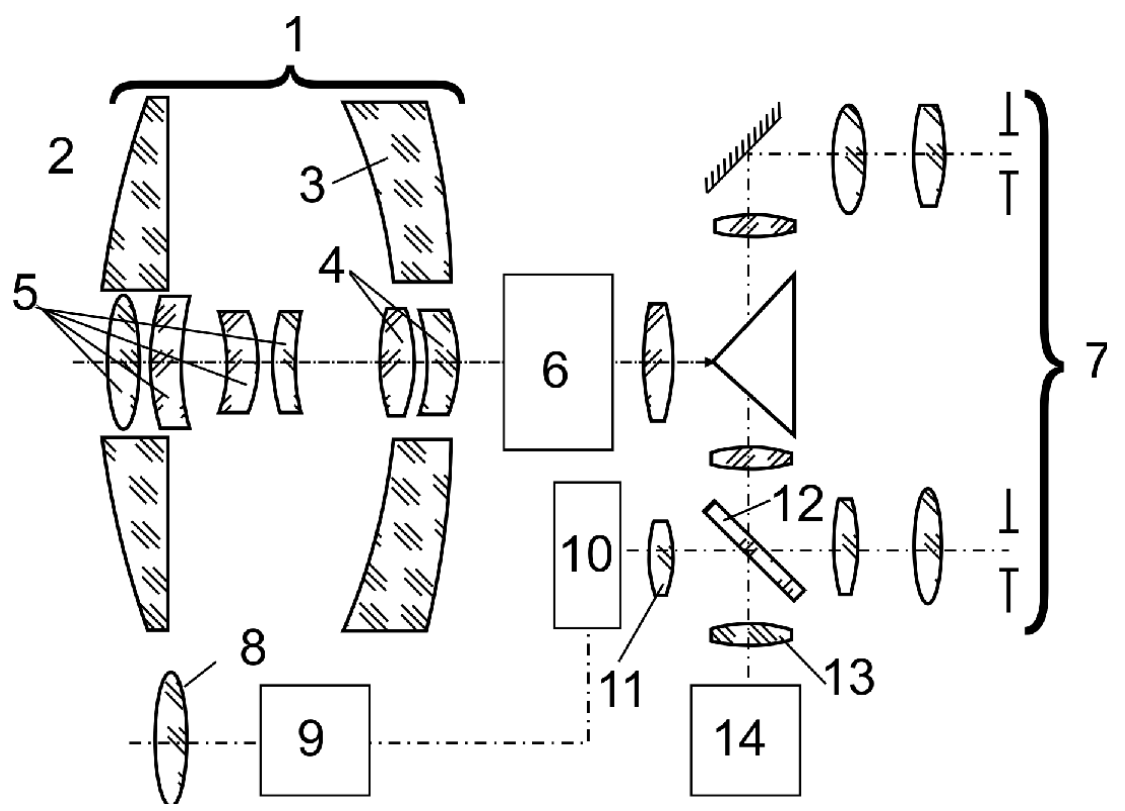

Рисунок. Схема псевдобинокулярных ОНВ.

\section{Литература}

[1] Гейхман И.Л., Волков В.Г. Видение и безопасность. М.: Новости. 2009. 840 с. 